\title{
Delimitation of two new species from the Grevillea victoriae alliance (Proteaceae: Grevilleoideae)
}

\author{
Peter M. Olde \& W.M. Molyneux
}

\begin{abstract}
Olde, Peter M. ${ }^{1}$ \& Molyneux W.M. ${ }^{2},\left({ }^{1} 138\right.$ Fowler Rd., Illawong, NSW 2234, Australia; ${ }^{2}$ P.O. Box 386, Yarra Glen, VIC 3775, Australia). 1994. Delimitation of two new species from the Grevillea victoriae alliance (Proteaceae: Grevilleoideae). Telopea 5(4): 781-787. McGillivray (1993) has submerged much population-based diversity in a broadly circumscribed Grevillea victoriae F. Muell. The G. victoriae complex is partially resolved by the delimitation of the new species G. hockingsii W. Molyneux \& P. Olde from south-eastern Queensland. G. mollis P. Olde \& W. Molyneux from the Northern Tablelands of New South Wales is also described.
\end{abstract}

\section{Introduction}

McGillivray (1993) treated G. victoriae F. Muell. as a polymorphic species complex consisting of 11 races. Three of these (Races j, k, l) include populations previously known as G. miqueliana F. Muell, one (Race g) includes G. victoriae var. leptoneura F. Muell. ex Benth. In addition, eight groups, some represented by a single specimen, are treated by MoGillivray as unassigned to race, including three specimens from the Biloela area, Queensland, here treated as a distinct species, G. hockingsii W. Molyneux \& P. Olde.

Recent collections from the Gibraltar Range, New South Wales, show that a second species most closely related to G. linsmithii McGillivray should be recognised. This is formally described here as G. mollis P. Olde \& W. Molyneux. Both new species are undoubtedly closely related and are probably part of a monophyletic alliance that includes G. linsmithii McGillivray, G. cyranostigma McGillivray, G. diminuta Johnson and perhaps G. aspera R.Br. and G. parallelinervis Carrick.

Bentham (1870: 423) placed G. victoriae and related species in his Sect. 8. Lissostylis, Series 1. Puniceae, a group united by the perianth undilated and revolute under the limb, torus straight, ovary glabrous, pollen-presenter lateral to very oblique, and leaves entire. McGillivray (1993: 454) placed G. victoriae in his Group 2 (2.2.1.1), a group sharing simple leaves and seeds revolute at the margin with an apical elaiosome and subapical pulvinus, and with a fine, downy covering of hair-like processes. All species also have a nodding perianth limb, a perianth narrowly ovate below the curve, and a pollen-presenter lateral and either obovate or elliptical.

This paper only partially resolves the diversity currently accommodated in G. victoriae, a species complex the subject of ongoing study by one of us (Molyneux). All species have been seen in the field or in cultivation. Conservation codes follow Briggs \& Leigh (1988). Species descriptions and terminology mostly follow McGillivray (1993).

\section{Taxonomy}

1. Grevillea mollis $P$. Olde \& $W$. Molyneux, sp. nov.

[Grevillea thymafolia M. Hodgson \& R. Paine (1977: 208), nomen invalidum, an English description published without reference to type and without Latin diagnosis.] 
A Grevillea linsmithii McGillivray fructibus longioribus (20-22 $\mathrm{mm}$ longis), conflorescentiis 6-20-floribus, perianthio longiore (13-14 mm longo), rubro, extus cum paucis trichomatibus brevissimis (c. $0.1 \mathrm{~mm}$ longis) erectisque, limbo subcubico, latiore (c. $3.5 \mathrm{~mm}$ lato), apice depresso, pistillis longioribus (16-17 $\mathrm{mm}$ longis) praebitore pollinis latiore (c. $3 \mathrm{~mm}$ lato); ab G. victoriae F. Muell. foliis mollibus, indumento perianthii sparso, conflorescentiis pistillisque plerumque brevioribus distinguitur.

HolotyPe: New South Wales: North Coast: Creek line, Dandahra Falls, Gibraltar Range National Park, P. Olde 93/45 \& D. Mason, 5 Sep 1993 (NSW). Isotypes: BRI, CANB, MEL.

Illustration: Hodgson \& Paine (1977: 209, Pl. 74) as G. thymafolia (sic).

An open, slender shrub, occasionally dense and spreading, 1-2 m high, 1-2 m wide; branchlets villous, round, slender. Leaves $2.8-10 \mathrm{~cm}$ long, $0.4-1.4 \mathrm{~cm}$ wide, ascending, shortly petiolate, simple, usually oblong to linear-oblong, sometimes elliptic to obovate, the apex obtuse-mucronate to acute, the base cuneate; upper surface dull, pubescent or with a sparse indumentum of spreading, biramous hairs, the venation brochidodromous and slightly raised, reticulum evident; margin entire, undulate, shortly recurved; lower surface with only the midvein and a few lateral veins prominent and with a moderately sparse, spreading indumentum of wavy to incurved biramous white hairs, the hairs on the veins usually rusty; texture chartaceous. Conflorescences 1-2 cm long, 2-3 cm wide, terminal on subterminal, decurved peduncles within the foliage, usually simple, occasionally 1-branched, loosely subcylindrical, few to many-flowered [6-12(-20)] with development acropetal; peduncles slender, 9-20 mm long, the apex $0.7 \mathrm{~mm}$ thick, loosely villous; floral rachis 4-14 $\mathrm{mm}$ long, loosely villous; floral bracts not seen. Flowers acroscopic to adaxially orientated; pedicels $3.5-4 \mathrm{~mm}$ long, loosely villous, usually incurved, oblique to the perianth; torus c. $1.5 \mathrm{~mm}$ across, cupuliform, oblique at c. $30^{\circ}$; nectary U-shaped, rising $0.4-0.6$ mm above the toral rim, the margin undulate; perianth 13-14 $\mathrm{mm}$ long, $3 \mathrm{~mm}$ wide, oblong-ovoid, with a very sparse indumentum of short erect white trichomes $0.05-0.1$ $\mathrm{mm}$ long outside and a dense indumentum of simple, reflexed hairs inside confined to the dorsal tepals in the lower half but condensed into a beard 6-8 $\mathrm{mm}$ from the base, the beard extending partially onto the ventral tepals; tepals with three raised ribs, cohering except along the dorsal suture before anthesis, all segments free to the beard after, the ventral tepals curled back further than the dorsal as two independent opposed pairs; limb $3.5 \mathrm{~mm}$ long, $3.5 \mathrm{~mm}$ wide, lateral, subcubic, apically depressed, the segments prominently keeled, separating and exposing the style-end before anthesis, the indumentum openly glandular-pubescent, sometimes with a few, appressed trichomes; pistil 16-17 mm long; stipe 1-1.5 mm long, glabrous; ovary glabrous or with scattered, erect trichomes; style slightly bowed out from the lower half of the dorsal suture before anthesis, glabrous in the lower half, with a sparse indumentum of short, erect trichomes in the upper half; pollen-presenter $2.8 \mathrm{~mm}$ long, $2.8-3 \mathrm{~mm}$ wide, lateral, flat to slightly concave, sometimes with raised medial ridge from the stigma to the base, obovate to almost square, the base concurrent with the style, the apex retuse; stigma scarcely prominent, distally off-centre. Fruits $20-22 \mathrm{~mm}$ long, 6-8 $\mathrm{mm}$ wide, erect to oblique on incurved and thickened stipes, ellipsoidal, faintly ribbed near the dorsal suture, otherwise smooth; style persistent, slightly dilated at the base and forming a knob-like apex on the fruit; pericarp $0.5 \mathrm{~mm}$ thick, \pm uniform in thickness throughout. Seed not seen. Figure 1.

EPITHET: Derived from the Latin mollis, soft, in reference to the leaf texture.

FLOWER COLOUR: Perianth and style scarlet; ovary green; stipe yellow; pollen-presenter green turning pinkish-yellow; pollen-grains white to pinkish-white.

FLOWERING PERIOD: Winter-spring and perhaps at other times. 
Distribution: New South Wales, where confined to the Gibraltar Range National Park.

CONSERVATION STATUS: $2 \mathrm{KC}$. The single known population is entirely contained within a National Park where c. 150 plants were found. Further searches of the area may find additional populations.

HABITAT \& ECOLOGY: Grows in local abundance on steep slopes of decomposed granite among granite rocks in scrub below eucalypts. Scattered plants with slightly broader leaves occur along the margins of Dandahra Creek. Regeneration is from seed. Several seedlings c. $10 \mathrm{~cm}$ high were observed at the collection site. Fruits persist well after dehiscence. Pollination is probably by nectarivorous birds.

Discussion: G. linsmithii McGillivray is most closely related to G. mollis but differs in its smaller fruits (17-18 mm long), its conflorescences usually with 2-4 flowers only, its smaller green perianth $(8-11 \mathrm{~mm}$ long) bearing a loosely subsericeous to subvillous outer surface and with the ovoid limb and upper perianth orange-pink to yellow-pink, the lower perianth narrower (c. $2 \mathrm{~mm}$ wide), its usually shorter pistils (11$16 \mathrm{~mm}$ long) with pollen-presenter narrower (c. $2.6 \mathrm{~mm}$ wide). G. mollis has longer fruits with an apiculum c. $5 \mathrm{~mm}$ long at the apex whereas in the few fruits of $G$. linsmithii seen the apiculum is not apparent. In its conflorescences with usually 6-20 flowers, its longer, all-red perianth bearing a sparse indumentum of very short erect trichomes on the outside and with a broader, subcubic, apically depressed limb and its pistils usually longer with a much broader pollen-presenter, G. mollis clearly warrants separation from $G$. linsmithii.
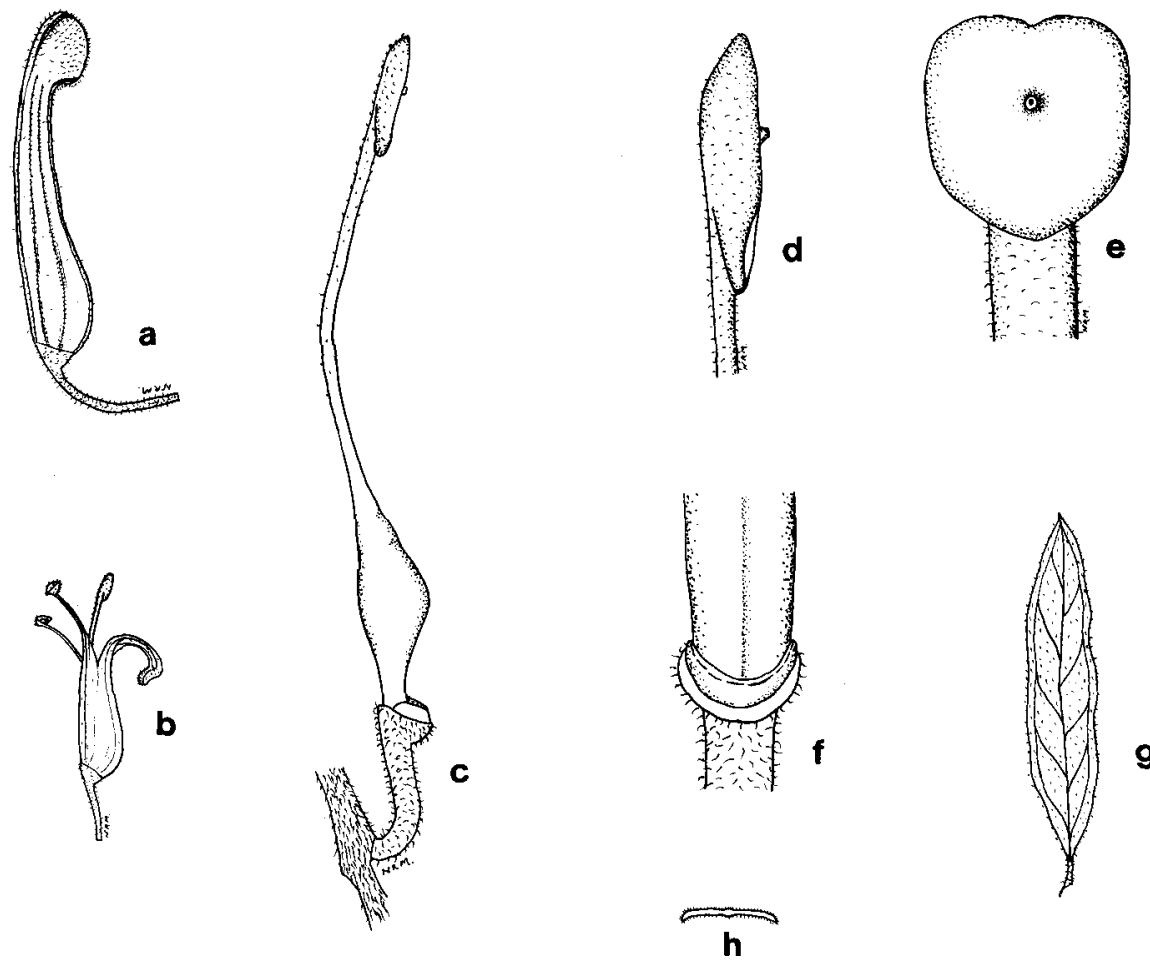

Figure 1. G. mollis. a. Perianth before anthesis (x2.5); b. Perianth after anthesis (x1.5); c. Pistil (x4.5); d. Style-end, side view (x7.5); e.. pollen-presenter (x7.5); f. nectary (x10); g. leaf (x0.5); h. leaf in cross-section (x0.5). 
G. victoriae F. Muell., with its 11 races and unassigned specimens as accepted by McGillivray, is also related but most races differ from $G$. mollis either in having an appressed indumentum on the lower leaf surface or in having thick, leathery leaves. Of the three races that share with $G$. mollis a spreading indumentum on the lower leaf surface (Races j, k, l), none has the sparse perianth indumentum of G. mollis, being usually villous or loosely so and the hairs with coloured contents. Only one population of $G$. victoriae sens. lat. (Race g sensu McGillivray) has the leaf texture of $G$. mollis. However, Race $g$ differs from $G$. mollis in its denser, more appressed indumentum on the leaf undersurface, its thicker peduncles, its slightly longer pistils and floral rachises and in its smoothly rounded, nodding perianth limb.

NOTE ON MORPHOLOGY: Perianth length is the distance measured just before anthesis at right angles from the mid-point of the torus to the top of the flower. In zygomorphic flowers this is usually where the perianth curves, not the apex of the limb.

Specimens Examined: New South Wales: Northern Tablelands: Beside walking track to Dandahra Falls, Gibraltar Range, Olde 93/45a \& Mason, 5 Sep 1993 (NSW); Dandahra Falls, Telford 10603, 9 Jun 1988 (NSW); northern NSW, Sheriff s.n., 1970 (NSW).

\section{Grevillea hockingsii W. Molyneux \& P. Olde, sp. nov.}

Affinis Grevilleae victoriae F. Muell. sed ab illa conflorescentiis plerumque axillaribus, simplicibus vel uni-ramosis, rhachidibus pro parte maxima brevioribus ( $2-8 \mathrm{~mm}$ longis), floribus paucis (plerumque c. 10 interdum 14), barba intus perianthium supra ovarium posita omnibus trichomatibus in longitudine eisdem, pistillis brevioribus (13-17.5 mm longis), fructibus longioribus, dorsaliter porcatis in extremis ambobus tumidis distinguitur.

Holotype: QueEnSLAND: Burnett: Coominglah State Forest, area of the Rockhole off Tuckers Rd, c. $27.7 \mathrm{~km} \mathrm{~W}$ of Monto, elevation c. $490 \mathrm{~m}$, Molyneux s.n \& Forrester, 12 Oct 1989 (MEL). Isotype: NSW.

A dense, floriferous, upright shrub (1-)1.5-2(-2.5) $\mathrm{m}$ high with ascending branches; branchlets angular, sericeous. Leaves (4-)7.5-9 \& 12-13(-14) cm long, (4-)8-12(-18) $\mathrm{mm}$ wide, shortly petiolate, simple (a single leaf once-lobed in a single specimen), oblong to narrow-elliptic, apex acute to obtuse with a short, soft mucro, rarely emarginate, purple-pink sericeous when young; upper surface when adult glabrous, smooth to slightly foveolate, sometimes granulate, shallowly concave; lower surface silvery-sericeous or with lightly ferruginous hairs intermixed; venation brochidodromous, raised on the upper surface, the lateral veins at $c .75^{\circ}$ to the midvein, the midvein prominently raised on the lower surface; margins shortly recurved. Conflorescences $1.5-2.2 \mathrm{~cm}$ long, 2-3 cm wide, variously erect to decurved, pedunculate, usually axillary, rarely terminal on short axillary branchlets, frequently cauline on older branches, usually simple, occasionally (c. 5\%) 1-branched, centrifugal, (6-)10(-14)-flowered; primary peduncles (4-)5-10(-15) $\mathrm{mm}$ long, terete to slightly elliptical in cross-section, loosely sericeous to lightly ferruginous-tomentose; secondary peduncles usually flattened in cross-section to subterete, arising sometimes on old peduncles; floral rachis $2-8 \mathrm{~mm}$ long, sericeous to loosely ferruginous-tomentose; floral bracts variable, 1-3.5 mm long, 0.4-1.6 mm wide, linear to lanceolate to narrowly triangular, margins revolute to strongly so and nearly concealing the inner surface, outer face ferruginousvillous, inner face similar, sometimes glabrous in the lower $2 / 3$, caducous when buds are c. $1.5 \mathrm{~mm}$ long. Flowers acroscopic; pedicels (3-)4(-7) $\mathrm{mm}$ long, sparsely whitesericeous or with ferruginous hairs intermixed; torus $1.5-1.9 \mathrm{~mm}$ across, square to slightly rectangular, oblique at $35-45^{\circ}$; nectary arcuate to $1 / 2$-annular with a flattened upper surface $0.30-0.5 \mathrm{~mm}$ deep; perianth $11-15 \mathrm{~mm}$ long, 2-2.5 mm wide, oblong, sparsely sericeous outside with scattered white and purple hairs, densely bearded inside $2-2.5 \mathrm{~mm}$ from the base, clearly above the ovary, sparsely hairy else- 
where, the trichomes sometimes spathulate or spoon-shaped; limb subcubic, $2 \mathrm{~mm}$ long and wide, $1.8-2 \mathrm{~mm}$ deep, nodding to almost revolute, densely sericeous; tepals separating along the dorsal suture before anthesis, at anthesis free at the apex and all rolling back equally for $3-4 \mathrm{~mm}$ as two independent opposed pairs, the ventral tepals ultimately rolled down c. $2 \mathrm{~mm}$ further; pistil 13-17.5 mm long; stipe 1-2.5 mm long, glabrous, vertically grooved on the ventral surface; ovary $1.5-2 \mathrm{~mm}$ long, glabrous, ovoid, scarcely wider than the style; style before anthesis bowed out through the dorsal suture of the perianth, sparsely pubescent, more densely so in the apical 5-6 mm, the trichomes short, erect, glandular; style-end c. $1 \mathrm{~mm}$ thick, sometimes emarginate; pollen-presenter $2-2.5 \mathrm{~mm}$ long, $1.8-2 \mathrm{~mm}$ wide, lateral, obovate to cordate, flat, decurrent with the ventral side of the style for c. $0.6 \mathrm{~mm}$; stigma slightly raised, distally off-centre. Fruit 20-36 mm long, 5-6.5 mm wide, 8-10 mm deep, strongly ribbed on the dorsal side, ellipsoidal to ovoid-ellipsoidal with a pronounced swelling at both ends, surface smooth to rugulose; style persistent; pericarp 0.3-0.4 $\mathrm{mm}$ thick. Seed 11-13 mm long, 3-4.5 mm wide, 1.5-2 mm thick, narrowly-ellipsoidal with an apical triangular elaiosome $2-3 \mathrm{~mm}$ long; margin recurved with a narrow waxy wing $0.2 \mathrm{~mm}$ wide. Figure 2 .

EPITHET: The specific epithet honours Mr F. David Hockings (1928- ), who discovered this species in Coominglah State Forest, Queensland in November 1983. Mr Hockings is a horticultural consultant and plant breeder, formerly an information officer with the Queensland Department of Primary Industry, who has devoted much of his life to the cultivation and wider public appreciation of the Australian flora.

FLOWER COLOUR: Perianth reddish-pink outside, mauve-pink inside; style reddish-pink.
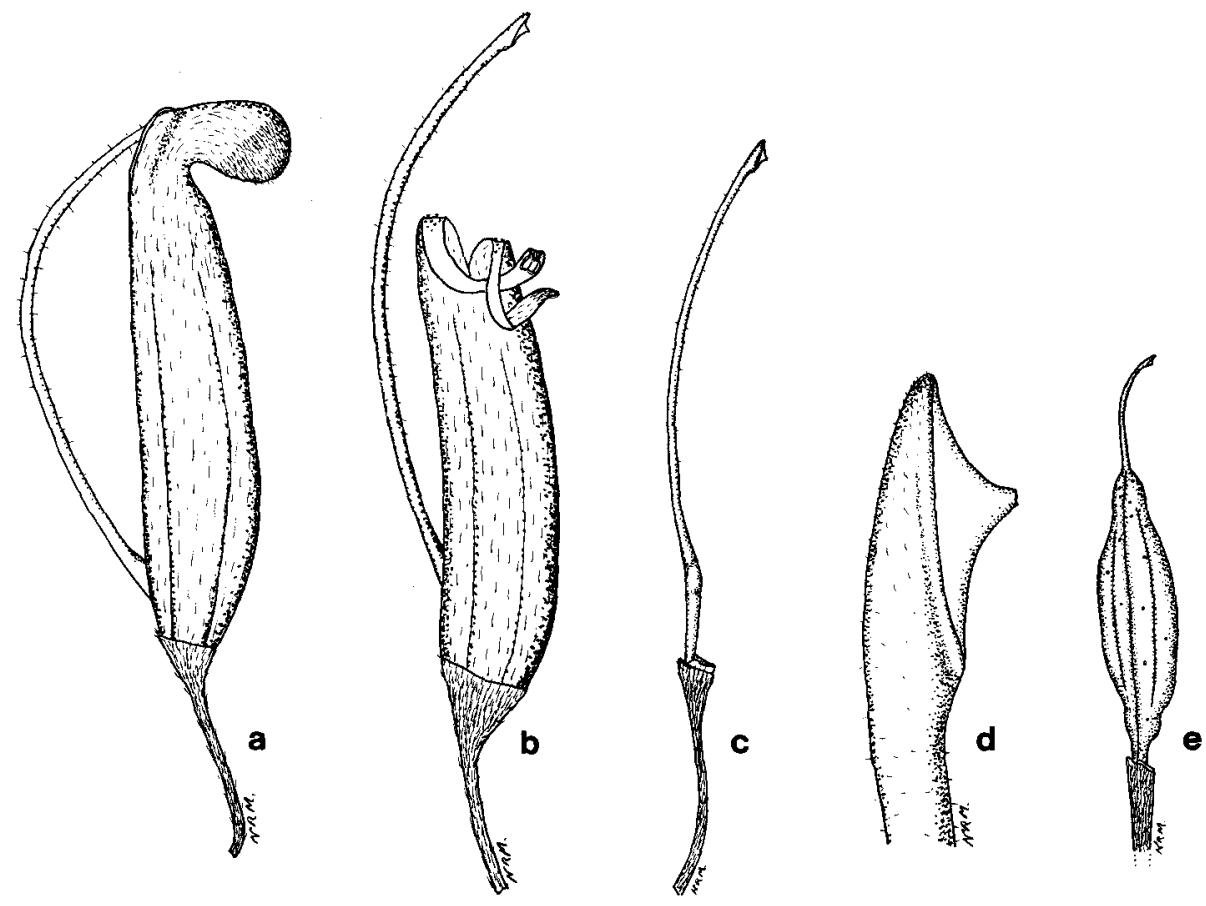

Figure 2. G. hockingsii. a. Perianth before anthesis $(x 5)$; b. Perianth after anthesis (x5); c. pistil (x4.5); d. style-end in side-view (x15); e. fruit (x1.5). 
FLOWERING PERIOD: (April-)June-December.

Distribution: Queensland with collections known from the Coominglah State Forest between Monto and Biloela and on the Razor Back Range W of Mt Morgan. A collection (not seen) has also been reported from the Callide Range, E of Biloela (R. Makinson pers. comm.).

Conservation status: A code of $3 \mathrm{~V}$ is recommended. The size and security of tenure of all populations warrants investigation.

HABITAT \& ECOLOGY: Grows in sandstone country, either on the edges of breakaways or on sandy flats in association with Eucalyptus maculata, E. decorticans, Boronia sp., Westringia sp., Goodenia sp., occasionally on the edge of soaks containing Callistemon sp. aff. salignus. Nectarivorous birds, possibly white-throated honeyeaters, have been observed feeding on the flowers.

Discussion: Grevillea hockingsii was included by McGillivray in G. victoriae as part of a group of specimens unassigned to race. It differs in its mostly axillary, unbranched (occasionally 1-branched) conflorescences with fewer (usually c. 10 but up to 14) and mostly smaller flowers, its generally shorter floral rachises (2-8 $\mathrm{mm}$ long) and pistils (13-17.5 mm long), the beard on the inner perianth positioned above the ovary and consisting of hairs of equal length, and in its usually longer fruits $(20-36 \mathrm{~mm})$ which are ribbed and have a short protuberance at both ends. Grevillea victoriae has mostly terminal, branched (up to 4-branched) conflorescences containing usually 16-22(-32) flowers, floral rachises $10-65 \mathrm{~mm}$ long, pistils $16-22.5(-26) \mathrm{mm}$ long and fruits smaller $(15-20 \mathrm{~mm})$, unribbed and without swellings at the ends. In G. victoriae, the ovary nestles within the beard of the inner perianth surface and consists of hairs of unequal length (the beard hairs on the dorsal tepals are longer than those on the ventral tepals). In addition, the conflorescences of $G$. hockingsii are sometimes cauline whereas those of G. victoriae never are. G. hockingsii develops buds and sets flower rather rapidly, unlike most other members of the $G$. victoriae complex which often set buds very early and hold them in an undeveloped state for many months. Flowering of $G$. hockingsii, while profuse, is mainly within the foliage and conflorescences form well back on the older wood as well as on recent growth. Some cauliflorous peduncles clearly arise above old leaf scars but others do not; in these cases they arise from a distinct pulvinus which develops on the stem at the base of the peduncle.

SELECTED SPECIMENS (5 examined): QueEnSLAND: Burnett: Coominglah State Forest, between Monto and Biloela, Hockings s.n., Sep 1983 (NSW); Monto, Bean 236, 20 May 1985 (BRI); Razor Back Range, c. $3 \mathrm{~km} \mathrm{~W}$ of Mt Morgan, E.R. Anderson 3797, 21 July 1984 (BRI); State Forest 28, 24 51'S $150^{\circ}$ 57'E, Forster 6717, 28 April 1990 (NSW, MEL, PERTH, AD, DNA, CANB, K, L, MO, BISH, LAE).

\section{Acknowledgements}

We would like to thank the Directors of BRI, MEL, NSW for providing access to their specimens and for sending loan material when requested. Neil Marriott gave considerable advice into aspects of the manuscript and provided the drawings as well. Dr L.A.S. Johnson kindly donated his time to peer-review this paper. 


\section{References}

Bentham, G. (1870) Flora australiensis, vol. 5 (Reeve \& Co.: London)

Briggs, J.D. \& Leigh, J.H. (1988) Rare or threatened Australian plants. Austral. Nat. Parks \& Wildlife Service, Special Publication No 14.

Hodgson M. \& Paine, R. (1977) A Field Guide to Australian Wildflowers, Vol. 2 (Rigby).

McGillivray, D.J. (1993) Grevillea. (Melbourne University Press: Melbourne)

Manuscript received 18 October 1993

Manuscript accepted 9 February 1994 